УДК 378:14

UDC 378:14

DOI: $10.31475 /$ ped.dys.2019.27.10

ОЛЬГА ПАВЛЕНКО, старший викладач

(Украӥна, Київ, Національний технічний університет Украӥни "Київський політехнічний інститут ілені Ігоря Сікорського", пр-m Перемоги, 37)

OLHA PAVLENKO, Senior Lecturer (Ukraine, Kyiv, National Technical University of Ukraine "Igor Sikorsky Kyiv Polytechnic Institute", Peremohy avenue, 37)

ORCID: 0000-0003-3233-6361

\title{
Професійна підготовка фахівців з електроніки у США: організація та мережа закладів вищої освіти
}

\author{
Professional Training of Electronics Engineers in the USA: \\ Organization and Network of Higher Education Institutions
}

Стаття висвітлюе питання організації закладів вищої освіти (далі - ЗВО) США та окреслюе особливості мережі закладів, які здійснюють профбесійну підготовку фбахівиів з електроніки на освітніх рівнях "бакалавр" та "магістр". Розглянуто особливості підходів до класифбікацї̈ ЗВО США. Наведено кількісні показники контингенту студентів в залежності від типу $3 В О$ та визначено три найпопулярніші типи американських ЗВО серед студентів. На основі порівняльного аналізу бази "Електрична та електронна інженерія" трвох світових систем ранжування закладів освіти з'ясовано кількісну та територіальну характеристику ЗВО, визначено закладилідери з підготовки фбахівиів з електроніки та охарактеризовано типи та структурні особливості ЗВО США. Встановлено, що серед досліджуваних закладів, половина знаходиться у державній власності, що зумовлене основним призначенням державних закладів - забезпечувати масовість освіти, а певна структурна неоднорідність підрозділів ЗВО США зуловлена їх високим рівнем інституційної автонолії.

Ключові слова: вища освіта США, заклад вищої освіти США, організація вищої освіти США, профбесійна підготовка, фбахівець з електроніки.

US higher engineering education is attracting more and more students these years. While the effectiveness of US higher engineering education is generally recognized, few studies have focused on the organization of higher education within a specific engineering specialism. In this article, the current situation of US higher engineering education is reviewed focusing especially on programs for electronics professionals. The article studies the organization of higher education institutions (HEI) in the USA and outlines the features of a network of HEIs that provide Bachelor's and Master's programs in electronics. This paper describes the approaches to classification of US HEIs, presents quantitative data on the number of students depending on the type of HEI, and identifies three most popular types of US HEIs that attract the highest number of students by offering degrees in electronics. Three most respected world ranking systems of HEIs were compared in order to determine quantitative and territorial characteristics of HEIs in the field of electrical and electronic engineering and identify the types of leading HEIs that provide training for potential professionals in the field of electronics. The findings reveal that structural characteristics of HEIs granting degrees in electronics appear to be heterogeneous. The results also showed that electronics education programs are mostly delivered by such institutions as colleges and schools, and the most common educational program covers the full regulatory period. It is found that among the surveyed US HEIs offering training for electronics professionals half of the institutions are state-owned, and the distinguishing feature of the vast majority of universities is their focus on high quality of research and development.

Key words: organization of US higher education, electronics engineer, US higher education institution, US higher education.

Вступ / Introduction. В сучасному світі електроніка входить до переліку галузей, які розвиваються найстрімкіше. Постійне удосконалення електронних приладів та пристроїв, стрімке впровадження наноелектронних технологій та інших передових розробок, ставить для країнлідерів в галузі електроніки завдання у підготовці висококваліфікованих кадрів та постійному 
оновленні освітніх програм. Відомо, що протягом останніх років одні 3 перших позицій проводжують займати США. Оскільки набуття та систематизація фахових знань майбутніми професіоналами в галузі електроніки здійснюеться в системі вищої освіти, вивчення досвіду США, а саме організація та мережа закладів вищої освіти для підготовки фахівців 3 електроніки представляють особливий інтерес для дослідження.

Структура сектору вищої освіти США, як правило, описується за класифікацією закладів вищої освіти Карнегі (Carnegie Classification). Починаючи з 1970 р., понад сорок років проводилося ii щорічне оновлення та вона стала своєрідним національним класифікатором (Алтбач Ф., 2015). 3 2015 р. нові видання класифікації готуе Центр післяшкільної (вищої) освіти Університету Індіани (Indiana University Center for Postsecondary Research) за спонсорської підтримки Фонду Луміна. Завданням сучасної класифікації Карнегі е не тільки проведення категоризації сектору вищої освіти США, але й відображення ії стану з огляду на цілу низку показників.

Чинне американське законодавство у сфері вищої освіти (Higher Education Opportunity Act, 1965) та Інститут педагогіки США, поділяють заклади вищої освіти США на державні та приватні (прибуткові та неприбуткові), які готують фахівців протягом $2-4$ років на трьох рівнях вищої освіти: бакалавр, магістр, доктор філософії. В США, як зазначае дослідниця О. Стойка, найпоширенішими вищими навчальними закладами е університети, коледжі та спеціалізовані інститути (Стойка О., 2017). Програми, за якими здійснюеться професійна підготовка з різних галузей знань в закладах вищої освіти США, повинні проходити процедуру акредитації.

Окремої уваги заслуговуе вивчення досвіду найвпливовіших американських ЗВО, що здійснюють підготовку фахівців з електроніки, забезпечують найвищу якість освітніх послуг i, разом з тим, посідають топові позиції у світових системах ранжування закладів освіти.

Мета та завдання / Aim and Tasks. Метою статті е аналіз організації та мережі ЗВО США з підготовки фахівців з електроніки. Завдання дослідження полягають у аналізі структури сектору ЗВО США у галузі електроніки та узагальненні даних корпусу досліджуваних ЗВО США, що здійснюють підготовку фахівців з електроніки.

Методи / Methods. 3 урахуванням поставлених завдань, в процесі дослідження було здійснено контент-аналіз літературних джерел та нормативно-правових документів. 3 метою вивчення особливостей організації американських ЗВО, було використано дані класифікації закладів освіти Карнегі (Carnegie Classification of Academic Institutions) та системи IPEDS (Integrated Postsecondary Education Data System) Національного центру освітньої статистики США. Мережу ЗВО та якість підготовки фахівців з електроніки, було досліджено за допомогою таких світових систем ранжування закладів освіти як THE (Times Higher Education World University Ranking), QS (QS World University Ranking), ARWU (Academic Ranking of World Universities), а також U.S. News.

Для визначення закладів вищої освіти, які пропонують акредитовані освітні програми 3 електроніки на двох рівнях: бакалаврському та магістерському в галузі електроніки, з бази даних Американської ради з акредитації у галузі інженерних наук і технологій ABET (American Board of Engineering Technology). за ключовими словами «Технології електронної інженерії» (англ. Electronics Engineering Technology) було відібрано 14 ЗВО. Таким чином, основний корпус американських ЗВО, що став предметом нашого дослідження, становить 43 заклади 3 підготовки фахівців у галузі електроніки: 29 топових університетів за інформацією світових систем ранжування і 14 згідно бази даних АВЕТ.

Результати / Results. Організація системи вищої освіти США. В ході дослідження було виявлено, що система організації вищої освіти США найкраще пердставлена у класифікації Карнегі. Відтак, відповідно до даної класифікації 2018 р., американські ЗВО розподіляються на шість категорій із врахуванням таких критеріїв, як найвищий ступінь, що присуджуеться, тривалість освітньої програми та науково-дослідницька діяльність, яка, у свою чергу, оцінюеться за загальним показником освітньої установи в цілому та частки цього показника у відношенні до кожного окремо взятого науково-педагогічного працівника.

Шість категорій класифікації Карнегі виглядають так:

1) докторські університети, які здійснюють підготовку за докторськими програмами;

2) університети та коледжі, що здійснюють підготовку за магістерськими програмами;

3) коледжі, що здійснюють підготовку за бакалаврськими програмами;

4) коледжі, що здійснюють підготовку за програмами молодшого спеціаліста (англ. associate’s degree);

5) спеціалізовані або вузькопрофрільні заклади;

6) коледжі для корінного населення (Carnegie Classification of Academic Institutions, 2018).

Більшість із названих вище категорій виділені на основі найвищого ступеню, який може присуджувати заклад. Проте освітні заклади можуть здійснювати підготовку і за нижчими ступенями. 
Глосарій термінів Національного центру освітньої статистики США бакалаврський рівень визначає як освітній ступінь, що присуджуеться в результаті виконання навчальної програми на рівні коледжу тривалістю від чотирьох до п'яти років. Сюди відносяться також п'ятирічні, так звані, комбіновані програми «навчання-робота», які передбачають поєднання навчання та трудової діяльності у сфері бізнесу, промисловості або урядування. Превагою таких дуальних програм $\epsilon$ можливість навчання паралельно з отриманням реального досвіду роботи (IPEDS, 2019).

Іншою особливістю американської системи вищої освіти $е$ наявність ступеню доктора професійної практики або діяльності. Ця категорія докторського ступеня походить від так званого «першого професійного ступеню». За даними IPEDS, термін та ступінь, який він позначав, вийшли з ужитку у 2010-2011 pр. у зв'язку із переглядом і запровадженням нових ступенів на рівні постбакалаврату (англ. postbaccalaurate), тобто після отримання ступеня бакалавру (IPEDS, 2011). 3 2011 р. ступенями та кваліфікаціями пост-бакалаврату є:

- ступінь магістра;

- пост-магістерський диплом;

- ступінь доктора науково-дослідницької діяльності;

- ступінь доктора професійної практики;

- ступінь доктора в іншій сфері діяльності.

Починаючи з 2011 р., так званий «професійний ступінь» або «ступінь професійної практики» визначаеться як ступінь доктора, що присуджуеться по завершенню шестирічної програми, яка забезпечуе отримання знань, вмінь та кваліфікації, необхідних для професійної діяльності (IPEDS, 2019).

Згідно редакції класифікації Карнегі за 2018 р. професійну підготовку на рівні бакалаврату та магістратури в галузі електроніки здійснюють ЗВО, які належать до першої-четвертої категорії 3 шести наведених вище (Carnegie Classification of Academic Institutions, 2018).

Кожен із названих типів освітніх закладів може пропонувати програми підготовки для отримання ступеню бакалавра. Різниця полягае в найвищому академічному ступені, який вони можуть присуджувати. Для коледжів, що здійснюють підготовку за бакалаврськими програмами та програмами молодшого спеціаліста - це програми на ступінь бакалавра. Наступною категорією $e$ коледжі, що здійснюють підготовку лише за бакалаврськими програмами. Університети та коледжі, що здійснюють підготовку за магістерськими програмами, пропонують також програми рівню бакалавра. Докторські університети пропонують програми підготовки, починаючи з ступеню бакалавра, далі - магістра з можливістю продовжувати навчання для отримання докторського ступеню.

3 часу опублікування першого офіційного видання класифікації в 1973 р. світ побачили вісім оновлених редакцій у 1976, 1987, 1994, 2000, 2005, 2010, 2015 та 2018 рр. Кожна з них відображала зміни, які відбувалися у структурі сектору вищої освіти США за попередні роки. На думку Ф. Алтбача, крім об’ективних факторів, які впливають на класифікацію Карнегі, е й суб’ективні, зокрема освітня політика, якої притримуеться спонсор (Фонд Карнегі до 2015 р. та Фонд Лумінан наразі) (Алтбача Ф., 2015). Тому, як вважає дослідник, кожна наступна редакція є відхиленням від початкової місії класифрікації - проведення простої та об’ективної категоризації закладів вищої освіти США, а не їхнього ранжування.

До прикладу, відмінністю класифікації в редакції 2015 р. е звернення особливої уваги на рівень підготовки за ступенем молодшого спеціаліста, який здійснюється відповідними коледжами (категорія «Associate’s Colleges» у класифікації) (Братко М., 2017).

Останнім виданням класифікації Карнегі е оновлена редакція за 2018 р., яка була оприлюднена у травні 2019. В оновленій класифікації особлива увага звертається на університети, що здійснюють підготовку за докторськими програмами (англ. doctoral universities) (табл. 1). Відповідна категорія була змінена для того, щоб додати показник «ступінь доктора професійної практики» до базової класифікації. За основними показниками, тобто кількістю навчальних закладів та чисельністю студентів станом на осінь 2017 р. класифікація має такий вигляд: 
Типи ЗВО США та кількість студентів відповідно до типу ЗВО (Класифікація Карнегі, 2018)

\begin{tabular}{|c|c|c|c|c|c|}
\hline \multirow[t]{2}{*}{ Тип закладу вищої освіти } & \multirow[t]{2}{*}{$\begin{array}{l}\text { Англомовний } \\
\text { еквівалент }\end{array}$} & \multicolumn{2}{|c|}{$\begin{array}{c}\text { Заклад вищої } \\
\text { освіти }\end{array}$} & \multicolumn{2}{|c|}{$\begin{array}{l}\text { Контингент } \\
\text { студентів } \\
\text { (осінь 2017) } \\
\end{array}$} \\
\hline & & Кількість & $\%$ & Кількість & $\%$ \\
\hline Докторські університети & Doctoral Universities & 418 & $10 \%$ & 7229265 & $36 \%$ \\
\hline $\begin{array}{lcc}\text { Університети } & \text { та коледжі, } & \text { що } \\
\text { здійснюють } & \text { підготовку } & \text { за } \\
\text { магістерськими програмами } & \end{array}$ & $\begin{array}{l}\text { Master's Colleges } \\
\text { and Universities }\end{array}$ & 685 & $16 \%$ & 3955922 & $20 \%$ \\
\hline 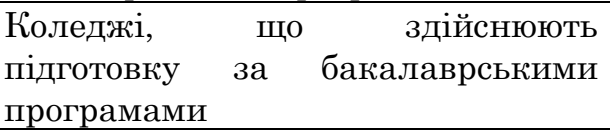 & $\begin{array}{l}\text { Baccalaureate } \\
\text { Colleges }\end{array}$ & 575 & $13 \%$ & 898818 & $4 \%$ \\
\hline $\begin{array}{l}\text { Коледжі, } \text { що } \\
\text { підготовку здійснюють } \\
\text { програмами ба такалаврськими } \\
\text { молодшого спеціаліста } \\
\end{array}$ & $\begin{array}{l}\text { Baccalaureate/Associ } \\
\text { ates }\end{array}$ & 262 & $6 \%$ & 1270740 & $6 \%$ \\
\hline $\begin{array}{lrr}\text { Коледжі, } & \text { що } & \text { здійснюють } \\
\text { підготовку } & \text { за } & \text { програмами } \\
\text { молодшого спеціаліста } & \\
\end{array}$ & Associate's Colleges & 1000 & $23 \%$ & 5808423 & $29 \%$ \\
\hline $\begin{array}{l}\text { Спеціалізовані } \\
\text { вузькопрофрільні дворічні коледжі }\end{array}$ & $\begin{array}{l}\text { Special Focus: Two- } \\
\text { Year }\end{array}$ & 432 & $10 \%$ & 183775 & $1 \%$ \\
\hline $\begin{array}{lr}\text { Спеціалізовані } & \text { або } \\
\text { вузькопрофрільні } & \text { чотирирічні } \\
\text { коледжі } & \end{array}$ & $\begin{array}{l}\text { Special Focus: Four } \\
\text { Year }\end{array}$ & 918 & $21 \%$ & 700442 & $3 \%$ \\
\hline Коледжі для корінного населення & Tribal Colleges & 34 & $1 \%$ & 16424 & $0,1 \%$ \\
\hline Загальна кількість & & 4324 & - & 20063809 & - \\
\hline
\end{tabular}

Як бачимо, станом на 2018 р. за контингентом студентів найпопулярнішими е три типи закладів вищої освіти: університети, що здійснюють підготовку за докторськими програмами, коледжі, що здійснюють підготовку за програмами молодшого спеціаліста, й університети та коледжі, що здійснюють підготовку за магістерськими програмами. Щодо кількості самих закладів вищої освіти найбільш представленими є коледжі, що здійснюють підготовку за програмами молодшого спеціаліста, спеціалізовані або вузькопрофільні коледжі з чотирирічними програмами підготовки, університети та коледжі, що здійснюють підготовку за магістерськими програмами, i коледжі, що здійснюють підготовку за бакалаврськими програмами.

Кожен із відображених у класифрікації типів закладів вищої освіти представлений двома формами власності: державною та приватною. Державні заклади вищої освіти створюються державними структурами різних рівнів. Їхня переважна більшість е освітніми закладами штатів або місцевими закладами вищої освіти (Козубовська І., Стойка О., \& Сідун Л., 2015). Приватний сектор вищої освіти США утворюють освітні заклади двох типів: прибуткові (комерційні) та неприбуткові (некомерційні).

Основними показниками сектору вищої освіти $е$ кількість навчальних закладів та чисельність студентів. 3 огляду на ці характеристики особливістю вищої освіти США е домінування закладів приватної форми власності, тобто наявність більшої кількості освітніх закладів недержавної форми власності. Проте за кількістю студентів перше місце посідає державний сектор, що великою мірою зумовлено основним призначенням державних освітніх закладів - забезпечувати масовість освіти (Козубовська І., Стойка О., \& Сідун Л., 2015).

Аналіз мережі ЗВО для підготовки фахівців з електроніки у США. Для проведення такого аналізу з метою забезпечення об’ективної інформації були використані дані світових рейтингів ЗВО, які пропонують освітні програми в галузі «Електрична та електронна інженерія». Найпрестижнішими світовими системами ранжування вважаються THE, QS та ARWU. Вибір цих рейтингів для нашого аналізу зумовлений їхньою міжнародною репутацією, переліком показників, на яких будуеться оцінка закладів вищої освіти, та географічною незалежністю (Царенко I., 2014; Дериховська В., 2016; Павленко О., 2018). Для порівняння додатково була включена американська система ранжування U. S. News.

Станом на вересень 2019 року загальний рейтинг THE на 2020 р. включає 1400 університетів із 92 країн (World University Rankings, 2019). Він сформований на основі 13 ретельно вивірених показників, що оцінюють діяльність закладу вищої освіти за якістю його навчальних послуг, 
дослідницькою діяльністю, трасферу знань та міжнародною репутацією.

Світова система ранжування QS використовуе шість критеріїв для оцінки діяльності університетів: 1) репутацію у сфері науки та навчання; 2) репутацію серед роботодавців; 3) співвідношення кількості викладацького складу і студентів; 4) рівень цитування на статті, що встановлюються на основі аналізу бази даних «Elsevier's Scopus» за останні п'ять-шість років; 5) частку іноземних викладачів; 6) частку іноземних студентів. Останні два критерії показують, наскільки привабливим е заклад вищої освіти для викладачів та абітурієнтів на світовому рівні, тобто дозволяють оцінити його міжнародну репутацію (QS World University Rankings Methodology, 2019).

Шанхайський або академічний рейтинг ARWU будуеться на основі аналізу шести критеріїв, які в основному спрямовані на визначення рівня науково-дослідницької діяльності закладу вищої освіти, наприклад, кількість випускників, які отримали Нобелівську премію або медаль Філдса; кількість найбільш цитованих дослідників за даними «Clarivate Analytics (Thomson Reuters)»; кількість наукових статей, опублікованих в журналах «Nature» i «Science»; кількість публікацій, індексованих в базі Science Citation Index, що включае як природничі та технічні науки, так і соціальні науки, а також співвідношення показників до кількості повних ставок академічних працівників (About Academic Ranking of World Universities, 2019). Тобто Шанхайський рейтинг оцінюе заклад вищої освіти насамперед як дослідницьку установу.

Система ранжування U.S. News. визначае, по-перше, найкращі світові університети і, по-друге, яке місце серед них посідають заклади вищої освіти США. Цей рейтинг укладається на основі 13 показників, які вимірюють насамперед науково-дослідницьку діяльність університетів, наприклад, кількість наукових публікацій, виданих книг, проведених конференцій, відсоток найбільш цитованих дослідників, міжнародна співпраця і т. ін. (Морз Р., \& Вега-Родрігес Х., 2019).

Кожна з описаних вище систем ранжування, крім загальних, подає також предметні світові рейтинги університетів. Вони визначають найкращі заклади вищої освіти в окремо взятій галузі. Предметний рейтинг ТНЕ на 2020 р., оприлюднений у вересні 2019 р., проводить ранжування світових лідерів серед університетів в 30 галузях знань, п'ять з яких пов'язані з інженерією, а саме: «Електрична та електронна інженерія», «Загальна інженерія», «Механічна та аерокосмічна інженерія», «Хімічна інженерія», «Цивільна інженерія».

Світова система ранжування QS визначае найвпливовіші університети в 48 галузях знань, використовуючи дані із чотирьох джерел. Перші два - це критерії загального рейтингу QS, a саме: репутація у сфері науки та навчання та думка роботодавців. Два інші показники дозволяють оцінити науково-дослідницьку діяльність навчального закладу на основі вирахування кількості цитувань кожної наукової статті та індексу Гірша у відповідній галузі (QS World University Rankings Methodology, 2019). Серед 48 галузей знань п’ять стосуються інженерії: «Видобувна та гірничотехнічна інженерія», «Електрична та електронна інженерія», «Механічна інженерія», «Хімічна інженерія», «Цивільна інженерія та проектування».

Шанхайський предметний рейтинг проводить ранжування університетів у п'яти галузях знань - природничі науки, інженерія, медико-біологічні науки, медичні науки та соціальні науки кожна 3 яких підрозділяеться на цілу низку окремих вузьких спеціальностей. Наприклад, інженерія включае 22 вузьких галузей знань, серед яких $е$ «Електрична та електронна інженерія» (Shanghai Ranking's Global Ranking of Academic Subjects, 2019).

Система ранжування U.S. News визначає лідерів серед світових закладів вищої освіти в 28 галузях знань на основі результатів їхньої науково-дослідницької роботи. Рейтинг формувався із залученням бібліометричних показників у «Web of Science» за п’ятирічний період з 2013 по 2017 pp. та різних індикаторів престижу навчального закладу на глобальному та регіональному рівнях (Морз Р., \& Вега-Родрігес X., 2019). Рейтинг U.S. News на 2020 р. включає шість нових галузей знань: «Електрична та електронна інженерія», «Механічна інженерія», «Онкологія», «Серцева та судинно-серцева системи», «Хірургія», «Цивільна інженерія». Як бачимо, «Електрична та електронна інженерія» знаходиться серед тих галузей знань, які були включені до системи ранжування цього року вперше, що свідчить про зростаючий інтерес до інженерних програм, зокрема у галузі електроніки.

Як свідчить аналіз світових предметних рейтингів, кожен з них проводить ранжування закладів вищої освіти і визначае найвпливовіші з них в галузі знань «Електрична та електронна інженерія». Система ранжування ТНЕ дозволяе визначити лідерів в певній галузі знань за окремими параметрами (наприклад, якість надання освітніх послуг, рівень науково-дослідницької діяльності, рівень цитувань, міжнародна репутація і т. ін.) та на основі всіх цих критеріїв вибраних одночасно.

Аналіз даних порівняльного дослідження світових предметних рейтингів закладів вищої освіти в галузі «Електрична та електронна інженерія» виявив, що перші 30 позицій займає 61 
освітня установа, розташована в 15 країнах світу. Інформація щодо територіального поширення цих топових навчальних закладів у кількісному відношенні представлена в табл. 2.

таблиия 2

Кількісна та територіальна характеристика ЗВО

в галузі «Електрична та електронна інженерія», які займають перші 30 позицій у світових системах ранжування закладів освіти THE, ARWU i QS

\begin{tabular}{|c|c|c|c|c|c|c|c|}
\hline $\begin{array}{l}\text { № } \\
\text { 3/п }\end{array}$ & Назва країни & $\begin{array}{c}\text { Кількість } \\
\text { ЗВО }\end{array}$ & $\begin{array}{c}\text { Відсоток, } \\
\%\end{array}$ & $\begin{array}{l}\text { № } \\
\text { 3/п }\end{array}$ & Назва країни & $\begin{array}{c}\text { Кількість } \\
\text { ЗВО }\end{array}$ & $\begin{array}{c}\text { Відсоток, } \\
\%\end{array}$ \\
\hline 1. & США & 29 & $47,5 \%$ & 9. & Швеція & 2 & $3,3 \%$ \\
\hline 2. & Китай & 8 & $13,1 \%$ & 10. & Канада & 1 & $1,6 \%$ \\
\hline 3. & $\begin{array}{l}\text { Об'єднане } \\
\text { Королівство } \\
\text { Великої Британії } \\
\text { й } \quad \text { Північної } \\
\text { Ірландії }\end{array}$ & 5 & $8,2 \%$ & 11. & Нідерланди & 1 & $1,6 \%$ \\
\hline 4. & Швейцарія & 3 & $4,9 \%$ & 12. & Італія & 1 & $1,6 \%$ \\
\hline 5. & Франція & 2 & $3,3 \%$ & 13. & Німеччина & 1 & $1,6 \%$ \\
\hline 6. & Південна Корея & 2 & $3,3 \%$ & 14. & Росія & 1 & $1,6 \%$ \\
\hline 7. & Японія & 2 & $3,3 \%$ & 15. & Данія & 1 & $1,6 \%$ \\
\hline 8. & Сінгапур & 2 & $3,3 \%$ & \multicolumn{2}{|c|}{ Всього: } & 61 & $100 \%$ \\
\hline
\end{tabular}

Як бачимо, серед країн, в яких знаходяться найпрестижніші заклади вищої освіти з підготовки фахівців з електроніки, е США, Китай, Об'єднане Королівство Великої Британії й Північної Ірландії, Швейцарія, Франція, Південна Корея, Японія, Сінгапур, Швеція, Канада, Нідерланди, Італія, Німеччина, Росія і Данія. Що стосуеться кількісного розподілу освітніх установ, як показують дані табл. 2, единим і безперечним лідером є США, де зосереджено 29 закладів, що стали предметом нашого порівняльного аналізу, тобто майже половина $(47,5 \%)$.

Серед них п'ять топових позицій займають 7 освітніх установ: Стенфордський університет, Массачусетський технологічний інститут, Каліфорнійський технологічний інститут, Єльський університет, Університет Каліфорнії (Берклі), Іллінойський університет (Урбана-Шампейн), Технологічний інститут Джорджії.

Окрім того, за результатами пошуку за ключовими словами "electronics engineering technology» у базі АВЕТ, до нашого дослідження було додано 14 американських ЗВО, які пропонують освітні програми з електроніки на двох рівнях: бакалаврському та магістерському.

У системі вищої освіти США підготовки фахівців за бакалаврськими програмами у галузі електроніки здійснюють коледжі, а магістерські програми зосереджені у докторських університетах, університетах та коледжах.

Відповідно до оновленої Класифікації Карнегі 2018 р., коледжі, що здійснюють підготовку за бакалаврськими програмами, поділяються на два підтипи відповідно до галузі, в якій пропонуються програми підготовки: 1) з фокусом на мистецтві та точних науках; 2) з фокусом на різноманітних галузях.

В свою чергу, докторські університети поділяються на три типи:

- докторські університети з дуже високим рівнем наукової діяльності (англ. Doctoral Universities: Very High Research Activity);

- докторські університети з високою науковою діяльністю (англ. Doctoral Universities: High Research Activity);

- докторські / професійні університети (англ. Doctoral / Professional Universities), відмінною рисою яких є низький рівень дослідницької активності.

У межах університетів та коледжів, що здійснюють підготовку за магістерськими програмами у Класифікації Карнегі (2018), виділяються три типи залежно від обсягу магістерських програм: 1) 3 великою кількістю програм; 2) з середньою кількістю програм; 3) з малою кількістю програм.

У ході дослідження було встановлено, що ЗВО, які стали предметом нашого розгляду, представлені докторськими університети двох типів: з дуже високою науковою активністю та професійними. Кількісні показники щодо типу проаналізованих освітніх установ зафіксовані в табл. 3. 
Кількісна характеристика ЗВО США

Таблиия 3

з підготовки фахівців з електроніки та їхній тип відповідно до класифікації Карнегі

\begin{tabular}{|c|c|c|c|c|c|}
\hline \multirow{2}{*}{ Тип закладу вищої освіти } & \multicolumn{5}{|c|}{ Кількість } \\
\hline & Всього & Відсоток, \% & 3 них & Всього & Відсоток, \% \\
\hline \multirow[t]{2}{*}{ Докторські університети } & \multirow[t]{2}{*}{36} & \multirow[t]{2}{*}{$83,8 \%$} & $\begin{array}{l}\text { 3 дуже } \\
\text { науковою активністю }\end{array}$ & 34 & $79,2 \%$ \\
\hline & & & Професійні & 2 & $4,6 \%$ \\
\hline \multirow{2}{*}{$\begin{array}{l}\text { Університети та коледжі, } \\
\text { що здійснюють підготовку } \\
\text { за магістерськими } \\
\text { програмами }\end{array}$} & \multirow{2}{*}{5} & \multirow{2}{*}{$11,6 \%$} & $\begin{array}{ll}\text { Велика } \\
\text { програм }\end{array}$ & 3 & $7 \%$ \\
\hline & & & $\begin{array}{ll}\text { Середня } & \text { кількість } \\
\text { програм } & \\
\end{array}$ & 2 & $4,6 \%$ \\
\hline $\begin{array}{l}\text { Коледжі, що здійснюють } \\
\text { підготовку } \\
\text { бакалаврськими } \\
\text { програмами }\end{array}$ & 2 & $4,6 \%$ & Різноманітні галузі & 2 & $4,6 \%$ \\
\hline \multicolumn{4}{|l|}{ Разом: } & 43 & $100 \%$ \\
\hline
\end{tabular}

Варто відзначити, що докторський університет з дуже високою науковою активністю $е$ найбільш репрезентованим серед досліджуваних нами освітніх установ. Тобто переважна більшість навчальних закладів вищої освіти, які готують фахівців з електроніки, (34 із 43 або 79,2 \%) за своїм типом належать до докторського університету, відмінної рисою якого, крім підготовки здобувачів 3 найвищим освітньо-кваліфікаційним рівнем, е висока якість науково-дослідницької діяльності. Прикладами цих закладів слугують Стенфордський університет, Массачусетський технологічний інститут, Іллінойський університет (Урбана-Шампейн), Технологічний інститут Джорджії, Гарвардський університет та багато інших. Як показують наведені приклади, категорія докторських університетів представлена закладами, які у своїх назвах містять слово «university» («університет») або «institute» («інститут»). Проте, незважаючи на назву, ці освітні установи відносяться до категорії докторських університетів.

У корпусі досліджуваних нами закладів $е$ також два докторські університети, які мають низьку наукову активність, відтак відносяться до професійних: Державний університет Ферріс і ПівнічноКентукський університет.

Із трьох підтипів категорії університетів та коледжів, що здійснюють підготовку за магістерськими програмами, $\mathrm{y}$ корпусі нашого дослідження представленими $е$ ті, що характеризуються наявністю великої кількості магістерських програм: наприклад, ПівнічноЗахідний державний університет Луїзіани, Університет Грентем і Блумсбургський університет; та із середньою кількістю, які представлені Державним університетом Томаса Едісона й Університетом Деврі. У порівнянні з докторськими університетами їхня кількість е незначною $(11,6 \%)$.

Серед коледжів, що здійснюють підготовку за бакалаврськими програмами, у корпусі освітніх установ, що розглядаються, наявні два заклади $(4,6 \%)$, які відносяться до категорії, що здійснюе підготовку фрахівців з фокусом на різноманітних галузях: Університет Пуерто-Ріко (Агуаділья) й Університет Пуерто-Ріко (Баямон). Варто вказати, що в обох назвах відсутній термін «коледж».

Щодо структурної організації проаналізованих нами освітніх установ варто відзначити, що у своїй переважній більшості це заклади, які складаються із окремих підрозділів із різними назвами: department, що українською, як правило, передається словом «факультет»; school - «школа» та college - «коледж». Незважаючи на назви, за їхніми функціями ці підрозділи можна прирівняти до факультетів. Необхідно зазначити, що слово «коледж» вживається в американському освітньому просторі для назви самостійного закладу вищої освіти, який пропонуе дво- та чотирирічні програми навчання, а також для позначення окремого підрозділу університету.

Особливістю структурної організації закладів вищої освіти США є відсутність такого підрозділу, як кафедра. Ї̈ функціональним еквівалентом виступае освітня програма, навколо якої об'єднуються науково-педагогічні кадри. На думку М. Братко, саме відсутність кафедри забезпечуе гнучкість структури університетів США та сприяе індивідуальній зоріентованості підготовки (Братко М., 2017).

У ході дослідження було встановлено, що в нашому корпусі закладів вищої освіти освітні програми в галузі електроніки здебільшого виконуються на базі двох підрозділів: коледжів та шкіл. Щодо коледжів, то це в основному коледжі інженерії, наприклад, Коледж інженерії Грейнджера (Іллінойський університет Урбана-Шампейн). Коледжі інженерії е в структурі таких університетів, як Університет Арканзасу (Літл-Рок), Державний університет Нью-Мексико, 
Корнелльський університет тощо. У деяких університетах освітні програми виконуються в коледжах інженерних та інших наук: наприклад, Коледж наукових досліджень та розробки технологій (Блумсбургський університет), Коледж інженерних й інформаційних наук (Університет Деврі), Коледж інженерії й технологій (Університет Східного Мічигану) та ін.

Школа інженерії як структурний підрозділ, що пропонуе освітньо-професійні програми в галузі електроніки, наявна в Стенфордському університеті, Массачусетському технологічному інституті, Гарвардському університеті, Університеті Джона Гопкінса, Нью-Йоркському університеті та ряді інших ЗВО.

Прикладами структурних підрозділів у дрормі факультетів (departments) e фракультет електроніки (Університет Пуерто-Ріко (Агуаділья)), факультет інженерії (Університет Пуерто-Ріко (Баямон), фракультет інженерної технології (Північно-Західний державний університет Луїзіани) та ін.

Як зазначалося вище, за формою фінансування заклади вищої освіти США поділяються на державні і приватні, які, в свою чергу, можуть бути некомерційні й комерційні (прибуткові). Відповідно до результатів нашого дослідження, серед проаналізованих нами освітніх установ більше половини (62,8 \%) державні заклади, наприклад, Університет Каліфорнії (Берклі), Університет Каліфорнії (Лос-Анджелес), Іллінойський університет (Урбана-Шампейн), Вашингтонський університет, Технологічний інститут Джорджії, Університет Мічигану (ЕннАрбор), Техаський університет (Остін) та інші. Державні освітні установи здебільшого $е$ університетами штатів і фінансуються ними.

Серед приватних закладів вищої освіти у нашій вибірці переважаюча більшість (14) $е$ некомерційними (32,6 \%), наприклад, Стенфордський університет, Массачусетський технологічний інститут, Каліфорнійський технологічний інститут, Єльський університет, Принстонський університет, Гарвардський університет, Пенсильванський університет, Університет Джона Гопкінса та інші. Як правило, ці установи функціонують на спонсорські кошти і мають великі ендаумент-фонди. До прикладу, на 2 жовтня 2019 р. ендаумент-фонд Стенфордського університету оцінювався в $\$ 27,7$ млрд. При цьому зазначалося, що протягом 2018 року університет отримав спонсорську допомогу від 72000 донорів (Stanford facts, 2019).

$\mathrm{y}$ корпусі досліджуваних нами освітніх установ е два приватних прибуткових навчальних заклади (4,6 \%): Університет Деврі та Університет Грентем. Обидва відносяться до університетів та коледжів, що здійснюють підготовку за магістерськими програмами.

Особливістю нашого аналізу е те, що в американських базах даних, так само, як і в програмах, практично не зустрічаеться повний еквівалент програми з назвою електроніка. Дослідження проводилося на базі таких освітніх програм: «Технології електронної інженерії», «Технології електротехніки й електронної інженерії», «Електротехніка», «Електротехнічна наука й інженерія», «Технології електроніки та комп’ютерної інженерії», «Електротехніка й комп’ютерна інженерія». Незважаючи на назву, в описовій частині кожної із проаналізованих програм вказувалося на електроніку як на основну галузь спеціалізації.

Наприклад, спеціальність «Електротехніка» Школи інженерії і прикладних наук Єльського університету включає широкий спектр дисциплін, а саме мікроелектроніку, фотоніку, комп’ютерну інженерію, обробку сигналів, системи керування, обробку і передачу інформації, які служать своерідним фундаментом для сучасного технологічного суспільства (Yale School of Engineering \& Applied Science, 2019).

Інші університети вказують електроніку та її підрозділи в описі предметної області освітньої кваліфікації, зазначаючи ї як пріоритетні напрями. Наприклад, на сайті Інженерних шкіл Фултона , що е підрозділом університету штату Арізона, а саме в описі спеціальності на ступінь бакалавра зазначається, що навчальна програма підготовки включае цілу низку курсів, які стосуються особливостей функціювання мікросхем, комунікацій, обробки сигналів та систем керування, комп'ютерної інженерії та напівпровідникових приладів (Ira A. Fulton Schools of Engineering, 2019).

Як показують результати нашого дослідження, освітні програми підготовки здобувачів для отримання рівня вищої освіти «магістр» поділяються на такі типи:

- освітня програма з повним нормативним періодом підготовки (англ. full-time);

- освітня програма подвійного ступеня (англ. joint degree program);

- освітня програма з режимом часткового навантаження (англ. part-time);

- прискорена освітня програма (англ. coterminal program).

Приклади всіх типів програм знаходимо у Стенфордському університеті. Освітня програма 3 повним нормативним періодом підготовки дозволяе отримати ступінь магістра технічних наук із спеціальності «Електротехніка». Такі самі можливості здобувачам надає прискорена програма, проте з вигідною перевагою: почати підготовку на ступінь магістра ще до закінчення бакалаврської 
програми.

Університет пропонуе дві магістерські програми подвійного ступеня. Відповідно, крім ступеня магістра технічних наук, здобувачі можуть отримати ступінь «Магістр бізнесу» або «Доктор юриспруденції.

Стенфордська магістерська освітня програма 3 режимом часткового навантаження зі спеціальності «Електротехніка» відома під назвою «Honors Cooperative program», що означає магістерську програму комбінованого навчання. Вона дозволяе отримати ступінь магістра технічних наук повністю дистанційно.

Таким чином, найбільш розповсюдженою е освітня програма з повним нормативним періодом підготовки. Освітня програма подвійного ступеня дозволяе студентам отримати два ступеня одночасно. Програма 3 режимом часткового навантаження розроблена для кваліфікованих працівників, які бажають поеднувати професійну діяльність з навчанням, і дозволяе проходити частину підготовки дистанційно. Прискорена програма призначена для студентів, які навчаються за програмою бакалаврату, i надає їм можливості розпочати підготовку за магістерською програмою одночасно з бакалаврською. Цим самим суттево скорочуеться термін навчання.

Обговорення / Discussion. Актуальність питання професійної підготовки фрахівців 3 електроніки у США в аспекті інженерної освіти, організації ЗВО та їх мережі знаходить підтвердження у працях багатьох дослідників. Зокрема, Л. Гребнев та В. Попов, в аналізі системи організації вищої технічної освіти США відзначають високий рівень впливу професійних спільнот та асоціацій на формування обсягу та змісту певних інженерних програм (Гребнев Л., \& Попов В., 2004). Результатми діяльності професійних спільнот на даному етапі е 14 акредитованих програм в галузік електроніки. Виділений Б. Рифкіним ряд тенденщій в американській вищій освіті, а саме активізація процесу навчання та зміна підходів до його організації, студентоцентровансіть та націленість на результати навчання, дозволили нам проаналізувати трансформацію підходів до фохової підготовки інженерів через десять років та вивчити їх в аспекті підготовки фрахівців з електроніки у ЗВО США (Рифкін Б., 2009). Це також підтверджуеться результатами дослідження О. Ігнатюк, яка вивчаючи підготовку майбутнього інженера в умовах технічного університету, стверджуе, що практика організації професійної освіти США показуе постійну готовність ЗВО та учасників освітнього процесу до оперативного реагування на необхідні зміни і коригування освітнього процесу для забезпечення високоякісної підготовки інженерних фахівців (Ігнатюк О., 2010).

Здобутки порівняльних досліджень ЗВО США та України О. Стойки, Б. Бистрової, а саме узагальнення американського досвіду підготовки фахівців, а також прогноз М. Згуровського щодо інноваційного розвитку вищої технічної освіти підтвердили багатогранний характер досліджень у сфері вищої інженерної освіти та визначили подальші пріоритети нашого дослідження підготовки фахівців з електроніки у ЗВО США (Стойка О., 2017; Бистрова Б., 2018; Згуровський М., 2018).

Висновки / Conclusions. Організація та мережа ЗВО США з підготовки фахівців 3 електроніки була досліджена з урахуванням типу ступеню, що присуджуеться, зокрема на освітніх рівнях «бакалавр» та «магістр», кількості навчальних закладів та чисельності студентів. Було встановлено, що у 2018 р. за кількістю студентів найпопулярнішими стали університети, що здійснюють підготовку за докторськими програмами, коледжі, що здійснюють підготовку за програмами молодшого спеціаліста, й університети та коледжі, що здійснюють підготовку за магістерськими програмами. За кількістю ЗВО у США найбільш представленими виявилися коледжі, що здійснюють підготовку за програмами молодшого спеціаліста, спеціалізовані або вузькопрофільні коледжі з чотирирічними програмами підготовки. Також, серед проаналізованих нами освітніх установ більше половини становили державні заклади, що підтверджуе стимулювання державою масового характеру освіти і відкриває більше можливостей для розвитку фахової підготовки інеженерів у сфері електроніки.

Здійснений аналіз трьох світових предметних рейтингів в розділі «Електрична та електронна інженерія» дозволив визначити лідера серед 15 країн - США, а також виділити топові ЗВО США серед перших 30 позицій світових рейтингів. Окрім того, кількісна характеристика ЗВО США 3 підготовки фахівців з електроніки, з огляду на їхній тип згідно класифікації Карнегі, показала, що майже $80 \%$ навчальних закладів, які готують фахівців з електроніки, належать до докторських університетів, відмінною рисою яких е висока якість науково-дослідницької діяльності, а певна неоднорідність структури ЗВО США, зокрема виконання освітніх програми в галузі електроніки на базі коледжів та шкіл, обумовлено їх інституційною автономіею.

Перспективали подальших наукових розвідок вважаємо дослідження формування змісту підготовки фахівців з електроніки у ЗВО США та впровадження досвіду інженерної освіти США в Україні. 


\section{Список використаних джерел і літератури:}

About Academic Ranking of World Universities. (2019). Retrieved from http://www.shanghairanking.com/aboutarwu.html [in English].

Altbach, P. G. (2015, May). The McCormic Classification of American Higher Education: More-and Less-Than Meets the Eye. International Higher Education, 80, 21-23 https://doi.org/10.6017/ihe.2015.80.6153 [in English].

American Board of Engineering Technology. (2019). Accredited programs. Retrieved from https://amspub.abet.org/aps/name-search?searchType=program\&keyword=electronics [in English].

Carnegie Classification of Academic Institutions. (2018). Bloomington: Center for Postsecondary Research

Indiana University School of Education. Retrieved from https://carnegieclassifications.iu.edu/downloads/CCIHE2018-FactsFigures.pdf [in English].
Educational attainment.
(2017).
US Census
Bureau.
Retrieved
from

https://factfinder.census.gov/faces/tableservices/jsf/pages/productview.xhtml?src=CF [in English].

Higher Education Opportunity Act 1965. (2008). Retrieved from https://www.gpo.gov/fdsys/pkg/PLAW110publ315/pdf/PLAW-110publ315.pdf [in English].

Integrated Postsecondary Education Data System 2011-12 Survey Materials. (2012). National Centre for

Education Statistics. Retrieved from https://nces.ed.gov/pubs2012/2012293.pdf[in English].

Integrated Postsecondary Education Data System 2019-20 Survey Materials: Glossary. (2019). National Center

for Education Statistics. Retrieved from https://surveys.nces.ed.gov/ipeds/Downloads/Forms/IPEDSGlossary.pdf [in English].

Ira A. Fulton Schools of Engineering. (2019). Retrieved from https://engineering.asu.edu/undergraduatedegree-programs/ [in English].

McCormic, A. C. (2006). The Carnegie Classification of Institutions of Higher Education. In A. C. McCormic OECD Workshop on Institutional Diversity. The Carnegie Foundation for the Advancement of teaching. Retrieved from http://www.oecd.org/education/imhe/37800086.pdf [in English].

Morse R., Vega-Rodriguez J. (2019). How U.S. News Calculated the Best Global Universities Rankings. U.S.News Education. Retrieved from https://www.usnews.com/education/best-globaluniversities/articles/methodology [in English].

QS World University Rankings Methodology. (2019). QS Top Universities. Retrieved from https://www.topuniversities.com/qs-world-university-rankings/methodology [in English].

Shanghai Ranking's Global Ranking of Academic Subjects 2019: Electrical \& Electronic Engineering. (2019). Academic Ranking of World Universities. Retrieved from http://www.shanghairanking.com/ShanghairankingSubject-Rankings/electrical-electronic-engineering.html [in English].

Stanford: Facts. (2019). Retrieved from https://facts.stanford.edu/ [in English].

World University Rankings. (2019). THE World University Rankings 2020. Retrieved from https://www.timeshighereducation.com/world-university-

rankings/2020/worldranking\#!/page/0/length/25/subjects/3135/sort by/rank/sort order/asc/cols/stats [in English].

Yale School of Engineering \& Applied Science. (2019). Retrieved from

https://seas.yale.edu/departments/electrical-engineering/undergraduate-study/undergraduate-curriculuminformation [in English].

Братко, М. В. (2017). Система освіти США: структура, традиції управління, особливості вищої освіти. Освітологічний дискурс, 3-4, 252-268. Взято з http://nbuv.gov.ua/UJRN/osdys 2017 3-4 22 [in Ukrainian].

Гребнев, Л., Попов, В. (2004). Об организации высшего технического образования в США. Высшее образование в России, 11, 150-165 [in Russian].

Дериховська, В. І. (2016). Порівняльна характеристика індикативного складу оцінки ВНЗ у міжнародних рейтингах. Економіка. Фінанси. Право (Економіка), 11, 26-30 [in Ukrainian].

Ігнатюк, О. (2010). Теоретичні та методичні основи підготовки майбутнього інженера до профбесійного самовдосконалення в умовах технічного університету. (Дис. д-ра. пед. наук). Харк. нац. пед. ун-т ім. Григорія Сковороди. Харків [in Ukrainian].

Козубовська, І. В., Стойка, О. Я, \& Сідун, Л. Ю. (2015). Історико-педагогічні аспекти розвитку вищої освіти в США (кінеиь XX - початок XXI століттл) [Монографія]. Ужгород: Видавництво ПП «АУТДОРШАРК» [in Ukrainian].

Павленко, О. В. (2018). Сучасний стан підготовки фахівців з електроніки в закладах вищої освіти США. Молодий вчений, 12 (64), 111-114 [in Ukrainian].

Рифкин, Б. (2009). О новых тенденциях в высшем образовании США. Высшее образование в России, 5, 127-133 [in Russian].

Стойка, О. Я. (2017). Вища освіта США та України: спільні та відмінні риси. Науковий вісник Ужгородського університету (Педагогіка. Соціальна робота), 1 (40), 280-283 [in Ukrainian].

Форсайт 2018: Аналіз підготовки і перепідготовки фбахівиів природничого і технічного спрямування, виходячи з иілей сталого соціально-економічного розвитку України до 2025 року. (2018). (с. 14-19). Київ: Політехніка» [in Ukrainian].

Царенко, І. О. (2014). Рейтингові системи ранжування вищих навчальних закладів: українські та світові методики. Наукові праці Кіровоградського національного технічного університету (Економічні науки) 26, 56-66 [in Ukrainian].

\section{References:}

http://www.shanghairanking.com/aboutarwu.html [in English].

Altbach, P. G. (2015, May). The McCormic Classification of American Higher Education: More-and Less-Than 
Meets the Eye. International Higher Education, 80, 21-23 https://doi.org/10.6017/ihe.2015.80.6153 [in English]. American Board of Engineering Technology. (2019). Accredited programs. Retrieved from https://amspub.abet.org/aps/name-search?searchType=program\&keyword=electronics [in English].

Carnegie Classification of Academic Institutions. (2018). Bloomington: Center for Postsecondary Research

Indiana University School of Education. Retrieved from

https://carnegieclassifications.iu.edu/downloads/CCIHE2018-FactsFigures.pdf [in English].
Educational
attainment.
(2017).
US Census
Bureau.
Retrieved
from

https://factfinder.census.gov/faces/tableservices/jsf/pages/productview.xhtml?src=CF [in English].

Higher Education Opportunity Act 1965. (2008). Retrieved from https://www.gpo.gov/fdsys/pkg/PLAW110publ315/pdf/PLAW-110publ315.pdf [in English].

Integrated Postsecondary Education Data System 2011-12 Survey Materials. (2012). National Centre for

Education Statistics. Retrieved from https://nces.ed.gov/pubs2012/2012293.pdf[in English].

Integrated Postsecondary Education Data System 2019-20 Survey Materials: Glossary. (2019). National Center for Education Statistics. Retrieved from https://surveys.nces.ed.gov/ipeds/Downloads/Forms/IPEDSGlossary.pdf [in English].

Ira A. Fulton Schools of Engineering. (2019). Retrieved from https://engineering.asu.edu/undergraduatedegree-programs/ [in English].

McCormic, A. C. (2006). The Carnegie Classification of Institutions of Higher Education. In A. C. McCormic OECD Workshop on Institutional Diversity. The Carnegie Foundation for the Advancement of teaching. Retrieved from http://www.oecd.org/education/imhe/37800086.pdf [in English].

Morse R., Vega-Rodriguez J. (2019). How U.S. News Calculated the Best Global Universities Rankings. U.S.News Education. Retrieved

universities/articles/methodology [in English].

QS World University Rankings Methodology. (2019). QS Top Universities. Retrieved from https://www.topuniversities.com/qs-world-university-rankings/methodology [in English].

Shanghai Ranking's Global Ranking of Academic Subjects 2019: Electrical \& Electronic Engineering. (2019). Academic Ranking of World Universities. Retrieved from http://www.shanghairanking.com/ShanghairankingSubject-Rankings/electrical-electronic-engineering.html [in English].

Stanford: Facts. (2019). Retrieved from https://facts.stanford.edu/ [in English].

World University Rankings. (2019). THE World University Rankings 2020. Retrieved from https://www.timeshighereducation.com/world-university-

rankings/2020/worldranking\#!/page/0/length/25/subjects/3135/sort_by/rank/sort_order/asc/cols/stats [in English].

Yale School of Engineering \& Applied Science. (2019). Retrieved from https://seas.yale.edu/departments/electrical-engineering/undergraduate-study/undergraduate-curriculuminformation [in English].

Bratko, M. V. (2017). Systema osvity SShA: struktura, tradytsii upravlinnia, osoblyvosti vyshchoi osvity [The Educational System of the USA: Structure, Traditions of Management, Features of Higher Education]. Osvitolohichnyi dyskurs - Educological Discourse, 3-4, 252-268. Retrieved from http://nbuv.gov.ua/UJRN/osdys_2017_3-4_22 [in Ukrainian].

Grebnev, L., Popov, V. (2004). Ob organizacii vy'sshego texnicheskogo obrazovaniya v SShA [On Ogranisation of Higher Education in the USA]. Vysshee obrazovaniye v Rossii - Higher Education in Russia, 11, 150-165 [in Russian].

Derykhovska, V. I. (2016). Porivnialna kharakterystyka indykatyvnoho skladu otsinky VNZ u mizhnarodnykh reitynhakh [Comparative Characteristics of Higher Education Assessment Indicative Components in International Ratings]. Ekonomika. Finansy. Pravo (Ekonomika) - Economics. Finance. Law (Economics), 11, 26-30 [in Ukrainian].

Ihnatiuk, O. (2010). Teoretychni ta metodychni osnovy pidhotovky maibutnoho inzhenera do profesiinoho samovdoskonalennia $v$ umovakh tekhnichnoho universytetu [Theoretical and Methodological Basis of Future Engineer Preparation for Professional Self-Improvement within the Context of Technical University] (Doctor's thesis). Kharkiv [in Ukrainian].

Kozubovska, I. V., Stoika, O. Ya, \& Sidun, L. Yu. (2015). Istoryko-pedahohichni aspekty rozvytku vyshchoi osvity v SShA (kinets KhKh - pochatok KhKhI stolittia) [Historical and Pedagogical Aspects of the Development of Higher Education in the USA] [Monograph]. Uzhhorod: Outdoor shark [in Ukrainian].

Pavlenko, O. V. (2018). Suchasnyi stan pidhotovky fakhivtsiv z elektroniky v zakladakh vyshchoi osvity SShA [Present Situation of Traning Electronics Specialists in US Higher Education Insitutions]. Molodyi VchenyiYoung scientist, 12 (64), 111-114 [in Ukraininan].

Rifkin, B. (2009). O novy'x tendenciyax v vy'sshem obrazovanii SShA [On New Trends in Higher Education in the USA]. Vysshee obrazovaniye v Rossii - Higher Education in Russia, 5, 127-133 [in Russian].

Stoika, O. Ya. (2017). Vyshcha osvita SShA ta Ukrainy: spilni ta vidminni rysy [Higher Education in Ukraine and the USA: Common and Different Features]. Naulovyi visnyk Uzhhorodskoho Universytetu (Pedahohika. Sotsialna robota) - Scientific bulletin of Uzhhorod University (Pedagogy. Social work), 1 (40), 280-283 [in Ukrainian].

Forsait 2018: Analiz pidhotovky i perepidhotovky fakhivtsiv pryrodnychoho $i$ tekhnichnoho spriamuvannia, vykhodiachy $z$ tsilei staloho sotsialno-ekonomichnoho rozvytku Ukrainy do 2025 roku [Foresight 2018: Analysis of the Training and Retraining of Specialists in the Natural and Technical Direction, Based on the Goals of Sustainable Socioeconomic Development of Ukraine by 2025]. (2018). (pp. 14-19). Kyiv: Politechnika [in Ukrainian].

Tsarenko, I. O. (2014). Reitynhovi systemy ranzhuvannia vyshchykh navchalnykh zakladiv: ukrainski ta svitovi metodyky [Rating Systems for Ranging Higher Educational Instituions: Ukrainian and International 
Methodologies]. Naukovi pratsi Kirovohradskoho natsionalnoho tekhnichnoho universytetu (Ekonomichni nauky) Collection of Scientific Works of Kirovohrad National Technical University (Economic Sciences), 26, 56-66 [in Ukrainian].

Дата надходження статті: «16» жовтня 2019 р.

Стаття прийнята до друку: «21» листопада 2019 р.

Павленко Ольга - старший викладач кафедри англійської мови технічного спрямування № 1 Національного технічного університету України «Київський політехнічний інститут імені Ігоря Сікорського»

Pavlenko Olha - Senior Lecturer of Department of English for Engineering № 1 of the National Technical University of Ukraine «Igor Sikorsky Kyiv Polytechnic Institute»

Цитуйте цљю статтю як:

Павленко, О. (2019). Професійна підготовка фахівців 3 електроніки у США: організація та мережа закладів вищої освіти. Педагогічний дискурс, 27, 84-95. doi: 10.31475/ped.dys.2019.27.10.
Cite this article as:

Pavlenko, O. (2019). Professional Training of Electronics Engineers in the USA: Organization and Network of Higher Education Institutions. Pedagogical Discourse, 27, 84-95. doi: 10.31475/ped.dys.2019.27.10. 